\title{
DETERMINAN STRUKTUR MODAL PADA PERUSAHAAN YANG TERDAFTAR DI JAKARTA ISLAMIC INDEX
}

\author{
Yogi Saputra ${ }^{\bowtie}$, Ummu Salma Al-Azizah, Yadi Nurhayadi
}

Universitas Muhammadiyah Prof. Dr. Hamka, Jakarta, Indonesia

syogi21@yahoo.co.id, ummusalma@uhamka.ac.id, yadinurhayadi@uhamka.ac.id

https://doi.org/10.46367/iqtishaduna.v10i2.419

Received: Oct 22, 2021 Revised: Nov 17, 2021 Accepted: Nov 25, 2021 Published: Des 17, 2021

\begin{abstract}
This study aimed to analyze the factors that influence the capital structure of companies listed on the Jakarta Islamic Index (JII). These factors consist of company size, return on assets (ROA), return on equity (ROE), inflation, and growth in the gross domestic product (GDP). This research is quantitative research with a purposive sampling method and obtained a sample of 9 companies. The data used is secondary data in financial reports on companies registered with JII in 2015-2019. Data analysis using the multiple linear regression method. The results showed that ROA had a significant adverse effect on the capital structure, ROE has a significant positive effect on the capital structure, firm size does not affect the capital structure, inflation does not affect the capital structure, GDP growth does not affect the capital structure. Simultaneously, firm size, ROA, ROE, inflation, and GDP growth significantly affect the capital structure.
\end{abstract}

Keywords: Capital Structure, Company Size, Profitability, Inflation, GDP Growth

\begin{abstract}
ABSTRAK
Tujuan dari penelitian ini adalah untuk menganalisis faktor-faktor yang mempengaruhi struktur modal pada perusahaan yang terdaftar di Jakarta Islamic Index (JII). Faktor tersebut terdiri dari ukuran perusahaan, return on assets (ROA), return on equity (ROE), inflasi dan pertumbuhan produk domestik bruto (PDB). Penelitian ini merupakan penelitian kuantitatif dengan metode pengambilan sampel adalah purposive sampling dan diperoleh sampel sebanyak 9 perusahaan. Data yang digunakan adalah data sekunder berupa laporan keuangan pada perusahaan yang terdaftar pada JII tahun 2015-2019. Analisis data menggunakan metode regresi linier berganda. Hasil penelitian menunjukkan bahwa ROA memberikan pengaruh signifikan secara negatif terhadap struktur modal. $R O E$ memberikan pengaruh signifikan secara positif terhadap struktur modal, ukuran perusahaan tidak berpengaruh terhadap struktur modal, inflasi tidak berpengaruh terhadap struktur modal, pertumbuhan PDB tidak berpengaruh terhadap struktur modal. Secara simultan ukuran perusahaan, $R O A, R O E$, inflasi dan pertumbuhan PDB berpengaruh signifikan terhadap struktur modal.
\end{abstract}

Kata Kunci: Struktur Modal, Ukuran Perusahaan, Profitabilitas, Inflasi, Pertumbuhan PDB. 


\section{PENDAHULUAN}

Pada tahun 1998, krisis yang dialami Indonesia merupakan salah satu krisis yang sangat memprihatinkan bagi negara, masyarakat maupun para pengusaha. Krisis saat itu diawali dengan jatuhnya nilai rupiah terhadap Dolar Amerika Serikat yang selanjutnya mengakibatkan harga-harga naik hingga tingkat inflasi mencapai lebih dari $77,5 \%$. Inflasi yang tinggi dapat mempengaruhi laba perusahaan sehingga menyebabkan penurunan keuntungan riil dan perusahaan akan membuat hutangnya menjadi lebih rendah (Setyanti 2009). Krisis finansial di Amerika Serikat pada tahun 2008 juga menjadi pembicaraan yang menarik hampir di seluruh dunia. Krisis ini disebabkan oleh kredit macet dari sektor property (subprime mortage), sejenis dengan kredit kepemilikan rumah (KPR) di Indonesia. Akibat dari krisis tersebut membuat beberapa perusahaan baik di Amerika Serikat maupun di negara lain bangkrut. Bagi negara-negara yang perekonomiannya masih bergantung dengan Amerika Serikat, tentu membuat keadaan ekonomi negara tersebut menjadi terganggu kondisi dan stabilitasnya. Bagi perusahaan yang memiliki dana cukup banyak, krisis tersebut tidak terlalu memberikan efek karena adanya cadangan modal yang cukup bagi perusahaan untuk tetap menjalankan kegiatan bisnisnya.

Penelitian terdahulu mengenai struktur modal, lebih banyak menggunakan faktor mikro ekonomi sebagai faktor yang mempengaruhi struktur modal dan belum banyak mengkaji pengaruh makro ekonomi terhadap struktur modal. Faktor yang mempengaruhi struktur modal antara lain seperti ukuran perusahaan, $R O A$, $R O E$, inflasi dan pertumbuhan PDB. Faktor ukuran perusahaan terhadap struktur modal pernah diteliti oleh Öztekin (2015); Wijayanti (2018); Astuti (2018). Namun dari penelitian tersebut menemukan hasil yang berbeda. Faktor $R O A$ terhadap struktur modal pernah diteliti oleh Firmanullah and Darsono (2017); Astuti (2018); Milansari, Masitoh, and Siddi (2020). Akan tetapi penelitian tersebut menemukan hasil yang berbeda juga. Faktor $R O E$ terhadap struktur modal juga pernah diteliti oleh Herciu and Ogrean (2017); Yulianto, Susyanti, and Salim (2018); Wijayanti (2018); Putra and Sedana (2019); Iqbal, Ahmad, and Ali (2019). Namun penelitian tersebut juga menemukan hasil yang berbeda.

Penelitian yang mengkaji pengaruh inflasi terhadap struktur modal belum banyak. Penelitian yang pernah mengkaji faktor inflasi terhadap struktur modal dilakukan oleh Budiono and Septiani (2017); Mukti Mahanani and Asandimitra (2017). Namun hasil penelitian tersebut juga menemukan hal yang berbeda pula. Sedangkan faktor pertumbuhan PDB terhadap struktur modal sudah pernah diteliti oleh Aktas, Bilge, and Celik (2015); Mahanani and Asandimitra (2017); Yildirim, Masih, and Bacha (2018). Akan tetapi hasil penelitian tersebut juga terdapat perbedaan. Berdasarkan penelitian-penelitian tersebut belum ditemukan penelitian yang mengkaji pengaruh faktor ukuran perusahaan, $R O A, R O E$, inflasi dan pertumbuhan PDB terhadap struktur modal. Sehingga hal tersebut dapat menjadi pembeda dengan penelitian-penelitian sebelumnya.

Perusahaan dalam menjalankan operasional, mengembangkan usaha, dan meningkatkan nilai perusahaan memerlukan modal dan merupakan salah satu aspek yang sangat penting bagi perusahaan (Sugeng 2017). Perusahaan yang tidak memiliki cukup modal akan mengalami kesulitan dalam menjalankan kegiatan operasionalnya, sehingga kecukupan modal sangatlah penting. Modal juga 
merupakan salah satu faktor untuk meningkatkan kualitas dan kuantitas akan produk dan jasa yang dihasilkan. Oleh sebab itu penelitian ini bertujuan untuk menunjukkan pengaruh ukuran perusahaan, $R O A, R O E$, inflasi dan pertumbuhan PDB terhadap struktur modal pada perusahaan yang terdaftar di JII. Sehingga penelitian ini dapat memberi sinyal kepada para calon investor dalam berinvestasi saham.

\section{TELAAH LITERATUR}

Struktur modal merupakan perbandingan modal sendiri dan modal eksternal yang digunakan dalam pengambilan keputusan mengenai kegiatan belanja perusahaan (Putri and Ruzikna 2016). Menurut Yildirim, Masih, and Bacha (2018) bahwa struktur modal merupakan campuran antara utang dan modal ekuitas perusahaan. Struktur modal menjadi salah satu bentuk keputusan yang sangat penting bagi perusahaan untuk menjalankan operasional perusahaan, khususnya jika keputusan struktur modal tersebut cenderung mempengaruhi posisi keuangan dan kemampuan perusahaan dalm berkompetisi dengan perusahaan lain (Yildirim, Masih, and Bacha 2018).

Dalam membuat keputusan struktur modal perusahaan, ada banyak hal-hal yang dapat mempengaruhinya. Berbagai penelitian dengan tema yang berhubungan dengan struktur modal pun juga telah banyak dilakukan, seperti current ratio dan ukuran perusahaan berpengaruh terhadap struktur modal (Milansari, Masitoh, and Siddi 2020); tingkat pertumbuhan perusahaan, stabilitas pendapatan dan struktur aktiva juga berpengaruh terhadap struktur modal (Istiqamah and Supriyanto 2017); serta pertumbuhan aset, pertumbuhan penjualan dan risiko bisnis (Firmanullah and Darsono 2017). Faktor-faktor tersebut merupakan faktor yang bersifat mikro ekonomi. Namun ada faktor-faktor yang tidak dapat dikendalikan oleh perusahaan, seperti kondisi makro ekonomi. Diantara makro ekonomi yang dapat mempengaruhi keadaan struktur modal perusahaan adalah keadaan inflasi, nilai tukar, tingkat pertumbuhan suatu negara, suku bunga, tingkat pajak dan sebagainya. Adapun faktor-faktor yang mempengaruhi struktur modal yang dibahas dalam penelitian ini terbatas pada ukuran perusahaan, $R O A, R O E$, inflasi dan pertumbuhan PDB.

Ukuran perusahaan dapat memberikan informasi untuk menentukan keputusan untuk menentukan keputusan berinvestasi para investor. Hal ini dikarenakan ukuran perusahaan dapat dijadikan salah satu acuan untuk menentukan besar kecilnya perusahaan. Ukuran perusahaan merupakan suatu ukuran yang dapat mengklasifikasikan perusahaan menurut berbagai cara, seperti total aset, nilai saham, jumlah penjualan dan sebagainya sehingga dapat disebut perusahaan besar atau kecil (Milansari, Masitoh, and Siddi 2020). Penelitian terdahulu mengenai pengaruh ukuran perusahaan memiliki hasil yang beragam. Menurut Naser et al. (2015); Gharaibeh (2015); Sumedrea (2015); Shah, Rashid, and Khaleequzzaman (2017); Akgul and Sigali (2018); Yildirim, Masih, and Bacha (2018); Iqbal, Ahmad, and Ali (2019); Albart et al. (2020), bahwa ukuran perusahaan berpengaruh signifikan dan positif terhadap struktur modal. Sedangkan menurut Öztekin (2015); Wijayanti (2018) ukuran perusahaan hanya berpengaruh positif terhadap struktur modal. Kemudian menurut Aktas, Bilge, and Celik (2015); El-Ansary and Hafez (2015); Fauziah and Iskandar (2015); Brian 
and Muriu (2017); Ramadhini and Hadziq (2017); Milansari, Masitoh, and Siddi (2020); bahwa ukuran perusahaan berpengaruh negatif dan signifikan terhadap struktur modal. Sedangkan menurut Berkman et al. (2016) ukuran perusahaan berpengaruh negatif terhadap struktur modal. Kemudian menurut Astuti (2018) ukuran perusahaan tidak berpengaruh terhadap struktur modal. Mayoritas dari penelitian yang sudah ada menyatakan ukuran perusahaan berpengaruh terhadap struktur modal, oleh sebab itu dapat dibentuk hipotesis pertama sebagai berikut:

$\mathbf{H}_{1}$ : ukuran perusahaan berpengaruh terhadap struktur modal.

ROA merupakan rasio yang dipakai untuk mengukur kemampuan manajemen perusahaan dalam memperoleh keuntungan secara keseluruhan berdasarkan aset yang dimiliki. ROA merupakan salah satu jenis rasio profitabilitas yang menilai kemampuan perusahaan memperoleh keuntungan berdasarkan aset Milansari, Masitoh, and Siddi (2020). Jika ROA perusahaan semakin besar, maka semakin besar pula tingkat keuntungan yang dicapai dan hal ini menunjukkan bahwa perusahaan sangat baik dalam memanfaatkan aset yang mereka miliki. Penelitian mengenai pengaruh ROA terhadap struktur modal juga menghasilkan temuan yang beragam. Menurut Aktas, Bilge, and Celik (2015); ElAnsary and Hafez (2015) ROA berpengaruh positif dan signifikan terhadap struktur modal. Kemudian menurut Brian and Muriu (2017); El-Ansary and Hafez (2015); Öztekin (2015); Shah, Rashid, and Khaleequzzaman (2017); Astuti (2018); Yildirim, Masih, and Bacha (2018) bahwa ROA berpengaruh negatif dan signifikan terhadap struktur modal. Sedangkan menurut Herciu and Ogrean (2017); Akgul and Sigali (2018); Iqbal, Ahmad, and Ali (2019) bahwa ROA berpengaruh negatif terhadap struktur modal. Sedangkan menurut Firmanullah and Darsono (2017); Albart et al. (2020); Milansari, Masitoh, and Siddi (2020) $R O A$ tidak berpengaruh terhadap struktur modal. Mayoritas dari penelitian yang sudah ada menyatakan $R O A$ berpengaruh terhadap struktur modal, oleh sebab itu dapat dibentuk hipotesis kedua sebagai berikut:

$\mathbf{H}_{2}$ : $R O A$ berpengaruh terhadap struktur modal.

Selain $R O A$, terdapat $R O E$ yang juga merupakan salah satu jenis rasio profitabilitas yang mampu menilai kemampuan perusahaan dalam hal memperoleh keuntungan dari ekuitas yang dimiliki. Menurut Ramadhini and Hadziq (2017) ROE merupakan rasio untuk mengukur kemampuan manajemen perusahaan dalam mengelola modal yang ada untuk mendapatkan profit atau laba. Dalam banyak penelitian tentang pengaruh $R O E$ terhadap struktur modal juga memberikan hasil yang beragam. Menurut Herciu and Ogrean (2017); Putra and Sedana (2019); Wijayanti (2018) ROE berpengaruh positif dan signifikan terhadap struktur modal. Menurut Ramadhini and Hadziq (2017) bahwa ROE berpengaruh positif terhadap struktur modal. Menurut Sumedrea (2015); Brian and Muriu (2017); Fauziah and Iskandar (2015); Gharaibeh (2015); Kontesa (2015); Astuti (2018); Rehan and Abdul Hadi (2019) bahwa ROE berpengaruh negatif dan signifikan terhadap struktur modal. Sedangkan menurut El-Ansary and Hafez (2015); Akgul and Sigali (2018); Yulianto, Susyanti, and Salim (2018); Iqbal, Ahmad, and Ali (2019); Albart et al. (2020) bahwa ROE berpengaruh negatif terhadap struktur modal. Mayoritas dari penelitian yang sudah ada menyatakan $R O E$ berpengaruh terhadap struktur modal, oleh sebab itu dapat dibentuk hipotesis ketiga sebagai berikut:

$\mathbf{H}_{3}: R O E$ berpengaruh terhadap struktur modal 
Inflasi merupakan kenaikan harga barang dan jasa secara umum selama periode waktu tertentu. Jika hanya satu atau dua barang yang mengalami kenaikan, maka tidak bisa disebut inflasi, kecuali jika kenaikan tersebut mengakibatkan kenaikan harga barang lainnya dan sifatnya meluas. Kenaikan harga akibat bencana alam, menjelang hari raya, musiman dan sebagainya yang bersifat sementara juga tidak disebut dengan inflasi. Dapat juga dikatakan bahwa inflasi sebagai penurunan daya beli orang, yang artinya makin tinggi kenaikan harga barang, maka semakin turun nilai uang. Penelitian tentang pengaruh inflasi terhadap struktur modal belum banyak. Adapun diantaranya penelitian yang dilakukan oleh Budiono and Septiani (2017); Ramadhini and Hadziq (2017); Yulianto, Susyanti, and Salim (2018) menyatakan bahwa inflasi berpengaruh positif terhadap struktur modal. Sedangkan menurut Öztekin (2015); Wijayanti (2018) bahwa inflasi berpengaruh negatif dan signifikan terhadap struktur modal. Menurut Aktas, Bilge, and Celik (2015); Shah, Rashid, and Khaleequzzaman (2017) bahwa inflasi berpengaruh negatif terhadap struktur modal. Sedangkan menurut Mahanani and Asandimitra (2017) bahwa inflasi tidak berpengaruh terhadap struktur modal. Mayoritas dari penelitian yang sudah ada menyatakan inflasi berpengaruh terhadap struktur modal, oleh sebab itu dapat dibentuk hipotesis keempat sebagai berikut:

$\mathbf{H}_{4}$ : inflasi berpengaruh terhadap struktur modal.

Pertumbuhan ekonomi adalah meningkatnya produksi barang dan jasa yang disebabkan adalnya perkembangan dalam perekonomian (Arifin and Soesatyo 2020). Menurut Rapanna and Sukarno (2017) bahwa pertumbuhan ekonomi biasanya diukur dengan menggunakan data PDB atau nilai akhir pasar (total market value) dari barang-barang akhir dan jasa-jasa yang dihasilkan dari suatu perekonomian selama kurun waktu tertentu, biasanya satu tahun. Penelitian mengenai pengaruh pertumbuhan PDB terhadap struktur modal juga belum banyak. Diantaranya adalah menurut Yildirim, Masih, and Bacha (2018); Aktas, Bilge, and Celik (2015) yang menyatakan bahwa adanya pengaruh negatif pertumbuhan PDB terhadap struktur modal. Sedangkan menurut Mahanani and Asandimitra (2017); Herciu and Ogrean (2017) yang menyatakan bahwa tidak ada pengaruh PDB terhadap struktur modal. Berdasarkan hasil penelitian tersebut maka dapat dibentuk hipotesis kelima sebagai berikut:

H5: pertumbuhan PDB berpengaruh terhadap struktur modal.

\section{METODE PENELITIAN}

Penelitian ini merupakan penelitian kuantitatif dan data yang digunakan adalah data sekunder. Duli (2019) menyatakan bahwa metode kuantitatif adalah metode yang melakukan kegiatan pengumpulan, pengolahan, analisis dan penyajian data berdasarkan objektifitas untuk menjawab suatu persoalan atau menguji sebuah hipotesis dalam mengembangkan prinsip-prinsip umum. Metode kuantitatif umumnya menggunakan data berupa angka dan analisisnya memakai teknik statistik. Data pada penelitian ini dikumpulkan melalui website resmi dari Bursa Efek Indonesia (BEI) yaitu https://www.idx.co.id/, berupa laporan keuangan perusahaan yang terdaftar di JII pada tahun 2015-2019 dan laporan keuangan yang terdapat dalam website resmi masing-masing perusahaan. 
Operasional variabel merupakan sebuah konsep yang mempunyai penjelasan dari variabel yang ditetapkan dalam penelitian yang bertujuan agar memastikan bahwa variabel yang diteliti memberikan penjelasan tentang indikator yang telah ditetapkan. Dalam penelitian ini, variabel bebas yang diuji adalah ukuran perusahaan, $R O A, R O E$, inflasi dan pertumbuhan $\mathrm{PDB}$, sedangkan variabel terikat adalah struktur modal.

Tabel 1. Operasional Variabel Terikat dan Variabel Bebas

\begin{tabular}{lc}
\hline \multicolumn{1}{c}{ Variabel } & Pengukuran \\
\hline Struktur Modal & DER $=\frac{\text { Total Debt }}{\text { Total Equity }}$ \\
Ukuran Perusahaan & $S I Z E=$ Ln (Total Aset) \\
ROA & $R O A=\frac{\text { Laba setelah pajak }}{\text { Total aset }}$ \\
ROE & $R O E=\frac{\text { Laba setelah pajak }}{\text { Total } \text { ekuitas }}$ \\
Inflasi & Laju inflasi yang tercatat dan \\
Pertumbuhan PDB & diterbitkan oleh Bank Indonesia \\
Sumber: olahan & Persentase pertumbuhan PDB
\end{tabular}

Populasi yang digunakan dalam penelitian ini adalah semua perusahaan yang terdaftar di JII berjumlah 30 perusahaan. Pemilihan sampel dilakukan berdasarkan metode purposive sampling. Adapun kriteria yang digunakan adalah: Pertama, perusahaan yang telah terdaftar di JII sejak tahun 2015 hingga 2019. Kedua, perusahaan memiliki dan mempublikasikan laporan keuangannya setiap 31 Desember pada akhir tahun sejak 2015 hingga 2019. Ketiga, perusahaan tidak memiliki struktur modal lebih dari 200\% setiap tahunnya. Keempat, perusahaan tidak merubah struktur modalnya lebih dari $100 \%$ dari tahun sebelumnya. Kelima, perusahaan tidak mengalami kerugian pada tahun 2015 hingga 2019. Dari 30 perusahaan, terdapat 16 perusahaan yang tidak terdaftar selama periode 2015 hingga 2019, 3 perusahaan yang memiliki struktur modal lebih dari 200\%, 1 perusahaan yang merubah struktur modalnya lebih dari $100 \%$ dan 1 perusahaan yang mengalami kerugian pada salah satu periode tersebut. Sehingga sampel yang digunakan dalam penelitian ini adalah sebanyak 9 perusahaan.

Penelitian ini menggunakan data sekunder, diperoleh dari berbagai sumber seperti www.idx.co.id, www.bi.go.id dan www.bps.go.id. Data struktur modal, ukuran perusahaan, $R O A$ dan $R O E$ diperoleh dari laporan keuangan perusahaan tahun 2015 hingga 2019. Sedangkan data inflasi diperoleh dari website resmi Bank Indonesia (BI) dan pertumbuhan PDB diperoleh dari website resmi Badan Pusat Statistik (BPS).

Analisa data menggunakan uji asumsi klasik (uji normalitas, uji autokorelasi, uji heterokedastisitas dan uji multikolinearitas), analisis regresi linier berganda, dan uji hipotesis. Adapun perangkat lunak yang digunakan untuk mengolah data adalah SPSS versi 24. Model analisis regresi linier berganda yang digunakan adalah sebagai berikut:

Dimana:

$$
\mathrm{Y}=\alpha+\beta_{1} \mathrm{X} 1+\beta_{2} \mathrm{X} 2+\mathrm{b}_{3} \mathrm{X} 3+\mathrm{b}_{4} \mathrm{X} 4+\mathrm{b}_{5} \mathrm{X} 5+\varepsilon
$$

$\mathrm{Y} \quad=$ Struktur Modal $(D E R)$ 


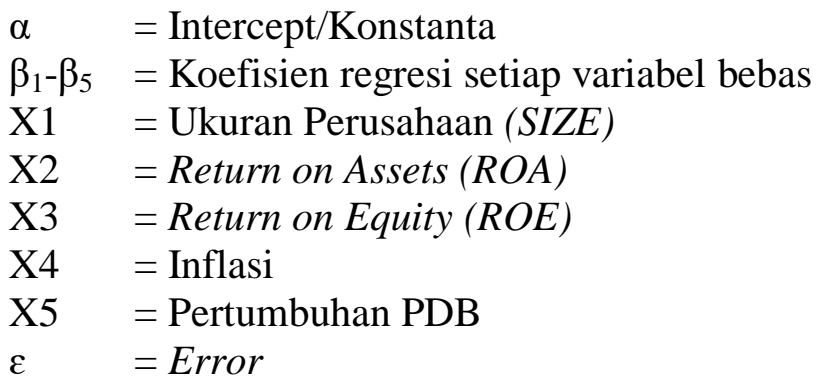

HASIL DAN PEMBAHASAN PENELITIAN

\section{Hasil Statistik Deskriptif}

Tabel 2. Hasil Statistik Deskriptif (Rata-Rata)

\begin{tabular}{lccccc}
\hline Variabel & $\mathbf{2 0 1 5}$ & $\mathbf{2 0 1 6}$ & $\mathbf{2 0 1 7}$ & $\mathbf{2 0 1 8}$ & $\mathbf{2 0 1 9}$ \\
\hline DER & 75,44 & 66,49 & 68,07 & 75,30 & 73,33 \\
SIZE & 24,71 & 24,76 & 24,87 & 25,00 & 25,04 \\
ROA & 7,89 & 9,19 & 10,26 & 9,05 & 8,62 \\
ROE & 13,26 & 14,83 & 16,83 & 15,38 & 14,38 \\
Inflasi & 3,35 & 3,02 & 3,61 & 3,13 & 2,72 \\
PDB & 5,15 & 4,94 & 5,19 & 5,18 & 4,97 \\
\hline \multicolumn{5}{l}{ Sumber: data sekunder (diolah) }
\end{tabular}

Berdasarkan Tabel 2 dapat dilihat, secara umum struktur modal perusahaan di JII tidak stabil. Hal ini dikarenakan kebutuhan perusahaan yang berbeda disertai keadaan perekonomian negara yang tidak cukup memberi kepastian bagi perusahaan. Ukuran perusahaan, sejak 2015 hingga 2019 cenderung mengalami peningkatan. Ini menunjukkan bahwa perusahaan di JII telah melakukan pengembangan yang cukup baik sehingga ukuran perusahaan terus meningkat.

$R O A$ dan $R O E$ menunjukkan rata-rata statistik yang sama, yaitu mengalami peningkatan pada tahun 2015, 2016 dan 2017. Kemudian mengalami penurunan pada tahun 2018 dan 2019. Ada kemungkinan imbas dari perang dagang antara Amerika Serikat dan China saat itu menjadi salah satu penyebab menurunnya kinerja perusahaan di dalam negeri. Selain itu, turunnya daya beli masyarakat serta penjualan ekspor yang fluktuatif juga bisa menjadi salah satu penyebab menurunnya kinerja perusahaan.

Sedangkan pada variabel inflasi menunjukkan adanya kestabilan harga di masyarakat. Ini merupakan salah satu keberhasilan pemerintah yang dapat mengendalikan tingkat inflasi di angka sekitar 3\%. Demikian juga ditunjukkan oleh pertumbuhan PDB yang stabil di angka 5\%. Tidak seperti inflasi yang dapat dikendalikan, stabilnya pertumbuhan PDB diangka 5\% menunjukkan bahwa pemerintah kesulitan untuk meningkatkan pertumbuhan ekonomi negara melalui produksi barang dan jasa. Sebagai akibatnya, kesejahteraan masyarakat tidak meningkat bahkan cenderung semakin kesulitan dalam meningkatkan kesejahteraannya. 


\section{Hasil Uji Asumsi Klasik}

Uji normalitas menggunakan one-sample kolmogorov-smirnov test. Tabel 3 menunjukkan bahwa data dalam penelitian ini terdistribusi normal atau dapat dikatakan memenuhi persyaratan uji normalitas. Hal tersebut ditunjukkan melalui nilai signifikansi (Asymp. Sig.) sebesar 0,116>0,05 sehingga dapat dikatakan bahwa data terdistribusi normal.

Tabel 3. Hasil Uji Normalitas

\begin{tabular}{lc}
\hline & Unstandardized Residual \\
\hline$N$ & 45 \\
Mean & 0,0000000 \\
Std. Deviation & 7,09494878 \\
Absolute & 0,107 \\
Positive & 0,097 \\
Negative & $-0,107$ \\
Test Statistic & 0,119 \\
Asymp. Sig. (2-tailed) & 0,116 \\
\hline Sumber: data sekunder (diolah) &
\end{tabular}

Uji autokorelasi merupakan alat ukur yang digunakan untuk mendeteksi adanya autokorelasi dalam penelitian ini, dengan menggunakan nilai DurbinWatson. Berdasarkan Tabel 4, dapat diketahui bahwa nilai Durbin-Watson sebesar 1,908. Nilai Durbin-Watson lebih besar dari pada DU $(1,776)$ dan lebih kecil daripada 4-DU $(4$ - 1,776), sehingga bisa dikatakan model ini bebas autokorelasi.

Tabel 4. Hasil Uji Autokorelasi

\begin{tabular}{ccccc}
\hline $\boldsymbol{R}$ & $\begin{array}{c}\boldsymbol{R} \\
\text { Square }\end{array}$ & $\begin{array}{c}\text { Adjusted } \boldsymbol{R} \\
\text { Square }\end{array}$ & $\begin{array}{c}\text { Std. Error of } \\
\text { the Estimate }\end{array}$ & Durbin-Watson \\
\hline 0,940 & 0,884 & 0,869 & 6,91759 & 1,908 \\
\hline
\end{tabular}

Sumber: data sekunder (diolah)

Uji heteroskedastisitas, menggunakan uji Glesjser dengan hasil seperti pada Tabel 5. Diketahui bahwa nilai probabilitas dari seluruh variabel bebas lebih besar dari 0,05 . Oleh karena itu, variabel dalam penelitian ini tidak terdapat gejala heteroskedastisitas.

Tabel 5. Hasil Uji Heteroskedastisitas

\begin{tabular}{lccc}
\hline & $\begin{array}{c}\text { Standardized } \\
\text { Coefficients }\end{array}$ & $\boldsymbol{t}$ & Sig. \\
\hline (Constant) & & 0,738 & 0,465 \\
SIZE & $-0,019$ & $-0,108$ & 0,914 \\
ROA & 0,318 & 0,759 & 0,452 \\
ROE & $-0,759$ & $-1,809$ & 0,078 \\
INFLASI & 0,189 & 0,840 & 0,406 \\
PDB & $-0,134$ & $-0,598$ & 0,553 \\
\hline Sumber: data sekunder (diolah) & &
\end{tabular}


Uji mulitikolinearitas dapat dilihat melalui nilai toleransi dan VIF (Variance Expansion Factor) dan syarat uji multikolinearitas adalah nilai VIF < 10 atau nilai toleransi $>0,10$. Hasil uji multikolinearitas dapat dilihat dari Tabel 6 . Dari seluruh variabel bebas didapat nilai toleransi lebih besar dari 0,01 dan nilai VIF lebih kecil 10. Maka dapat dikatakan bahwa seluruh variabel dalam penelitian tidak menunjukkan masalah multikolinearitas sehingga penelitian dapat dilanjutkan.

\begin{tabular}{|c|c|c|}
\hline \multirow{2}{*}{ Model } & \multicolumn{2}{|c|}{ Collinearity Statistics } \\
\hline & Tolerance & VIF \\
\hline SIZE & 0,638 & 1,568 \\
\hline$R O A$ & 0,109 & 9,147 \\
\hline$R O E$ & 0,109 & 9,158 \\
\hline Inflasi & 0,379 & 2,642 \\
\hline PDB & 0,381 & 2,627 \\
\hline
\end{tabular}

Sumber: data sekunder (diolah)

\section{Hasil Regresi Linier Berganda}

\begin{tabular}{|c|c|c|c|c|}
\hline & \multicolumn{2}{|c|}{$\begin{array}{l}\text { Unstandardized } \\
\text { Coefficients }\end{array}$} & \multirow[t]{2}{*}{$t$} & \multirow[t]{2}{*}{ Sig. } \\
\hline & $\boldsymbol{\beta}$ & Std. Error & & \\
\hline (Constant) & 90,696 & 84,897 & 1,068 & 0,292 \\
\hline SIZE & $-2,573$ & 1,569 & $-1,640$ & 0,109 \\
\hline$R O A$ & $-15,247$ & 0,943 & $-16,174$ & 0,000 \\
\hline$R O E$ & 8,778 & 0,649 & 13,529 & 0,000 \\
\hline Inflasi & $-4,981$ & 6,458 & $-0,771$ & 0,445 \\
\hline PDB & 13,159 & 17,905 & 0,735 & 0,467 \\
\hline \multicolumn{3}{|l|}{ Adj R-Square } & & 0,895 \\
\hline \multicolumn{3}{|c|}{ F-Statistic } & & 75,629 \\
\hline \multicolumn{3}{|c|}{ Sig. (F-Statistic) } & & 0,000 \\
\hline
\end{tabular}

Berdasarkan Tabel 7, nilai koefisien dari tiap variabel independen dapat diketahui dari kolom Unstandardized Coefficients pada kolom $\beta$. Sehingga dapat diperoleh persamaan regresinya sebagai berikut: $D E R=90,696-2,573$ SIZE $15,247 R O A+8,778 R O E-4,981$ Inflasi $+13,159 \mathrm{PDB}+\varepsilon$. Nilai konstanta sebesar 90,696 artinya apabila variabel SIZE, ROA, ROE, inflasi dan PDB bernilai 0, maka nilai DER sebesar 90,696. Nilai koefisien SIZE sebesar -2,573 artinya apabila $R O A$, ROE, inflasi dan PDB bernilai 0 dan SIZE mengalami kenaikan sebesar 1 maka nilai $D E R$ mengalami penurunan sebesar 2,573. Koefisien bernilai negatif artinya terjadi hubungan negatif antara SIZE dengan $D E R$ atau jika nilai SIZE naik, maka nilai DER turun. Nilai koefisien $R O A$ sebesar $-15,247$ artinya apabila variabel SIZE, ROE, inflasi dan PDB bernilai 0 dan $R O A$ mengalami kenaikan sebesar 1 maka nilai $D E R$ mengalami penurunan sebesar 15,247. 
Koefisien bernilai negatif artinya terjadi hubungan negatif antara $R O A$ dengan $D E R$ atau jika nilai $R O A$ naik, maka nilai $D E R$ akan turun.

Nilai koefisien $R O E$ sebesar 8,778 artinya apabila variabel SIZE, ROA, inflasi dan PDB nilainya nol atau konstan dan $R O E$ mengalami kenaikan sebesar 1 maka nilai $D E R$ mengalami kenaikan sebesar 8,778. Koefisien bernilai positif artinya terjadi hubungan positif antara $R O E$ dengan DER atau jika nilai $R O A$ naik, maka nilai $D E R$ juga naik. Nilai koefisien inflasi sebesar $-4,981$ artinya apabila variabel SIZE, ROA, ROE dan PDB bernilai 0 dan inflasi mengalami kenaikan sebesar 1 maka nilai $D E R$ mengalami penurunan sebesar 4,981. Koefisien bernilai negatif artinya terjadi hubungan negatif antara inflasi dengan $D E R$ atau jika nilai inflasi naik, maka nilai DER akan turun. Nilai koefisien PDB sebesar -13,159 artinya apabila variabel SIZE, ROA, ROE dan inflasi nilainya nol atau konstan dan PDB mengalami kenaikan sebesar 1 maka nilai DER mengalami penurunan sebesar 13,159 . Koefisien bernilai positif artinya terjadi hubungan positif antara PDB dengan DER atau nilai PDB naik, maka nilai DER akan naik.

Berdasarkan Tabel 7, hasil determinasi model ini menunjukkan nilai 0,895 . Nilai tersebut menunjukkan bahwa variabel independen yang terdiri dari SIZE, ROA, ROE, inflasi dan PDB mampu menjelaskan variabel dependen sebesar $89,5 \%$ terhadap variabel dependen yaitu $D E R$, sementara sisanya sebesar $10,5 \%$ dipengaruhi oleh variabel independen yang tidak digunakan atau dijelaskan dalam penelitian ini.

\section{Hasil Uji Hipotesis}

Tabel 7 menunjukkan bahwa nilai $F_{\text {hitung }}$ sebesar 76,629 $>F_{\text {tabel }}$ 2,456 dan signifikansi $0,000<$ taraf signifikansi 0,05 , sehingga dapat dikatakan bahwa seluruh variabel bebas secara bersama-sama berpengaruh signifikan terhadap variabel terikat, yaitu struktur modal $(D E R)$. Hal ini menunjukkan bahwa ukuran perusahaan (SIZE), ROA, ROE, inflasi dan pertumbuhan PDB secara bersamasama mempengaruhi keputusan perusahaan dalam membuat keputusan mengenai struktur modal perusahaannya. Dari lima variabel tersebut, profitabilitas perusahaan (ROA) yang paling banyak memberikan pengaruh terhadap struktur modal. Jika perusahaan mendapat laba yang besar, mereka memilki lebih banyak pilihan untuk mengatur struktur modal perusahaan pada masa mendatang.

Perlu diketahui bahwa penelitian menggunakan nilai signifikansi $\alpha=0,05$ dan nilai $t_{\text {tabel }}$ sebesar 2,023. Berdasarkan Tabel 7 dapat diketahui bahwa nilai $\mathrm{t}_{\text {hitung }}$ SIZE sebesar -1,640 $(-2,023<-1,640<2,023)$ dan signifikansi sebesar 0,109 $>$ 0,05. Maka dapat dikatakan bahwa hipotesis $\mathbf{H}_{\mathbf{1}}$ ditolak, artinya SIZE atau ukuran perusahaan tidak berpengaruh terhadap struktur modal. Kemudian nilai $\mathrm{t}_{\text {hitung }} R O A$ sebesar $-16,174<-2,023$ dan signifikansi sebesar 0,000 $<0,05$. Maka dapat dikatakan bahwa hipotesis $\mathbf{H}_{2}$ diterima, artinya $R O A$ berpengaruh signifikan terhadap struktur modal. Sebagai informasi tambahan bahwa pengaruh yang diberikan adalah negatif.

Pada Tabel 7 dapat dilihat bahwa nilai $t_{\text {hitung }} R O E$ sebesar 13,529 > 2,023 dan signifikansi sebesar $0,000<0,05$. Maka dapat dikatakan bahwa hipotesis $\mathbf{H}_{3}$ diterima yang artinya bahwa $R O E$ berpengaruh signifikan terhadap struktur modal. Sebagai informasi tambahan bahwa pengaruh yang diberikan adalah positif. Kemudian nilai $t_{\text {hitung }}$ inflasi sebesar $-0,771 \quad(-2,023<-0,771<2,023)$ dan signifikansi sebesar 0,445 > 0,05. Maka dapat dikatakan bahwa hipotesis $\mathbf{H}_{4}$ 
ditolak, artinya inflasi tidak berpengaruh terhadap struktur modal. Selanjutnya nilai $t_{\text {hitung }}$ PDB sebesar $0,735(-2,023<0,735<2,023)$ dan signifikansi sebesar $0,467>0,05$. Maka dapat dikatakan bahwa hipotesis $\mathbf{H}_{5}$ ditolak yang artinya pertumbuhan PDB tidak berpengaruh terhadap struktur modal.

\section{Pembahasan}

Hasil hipotesis $\mathbf{H}_{\mathbf{1}}$ ditolak, artinya ukuran perusahaan tidak berpengaruh terhadap struktur modal. Hasil penelitian ini sejalan dengan penelitian yang dilakukan oleh Astuti (2018) yang menyatakan bahwa ukuran perusahaan tidak berpengaruh terhadap keputusan struktur modal. Hal tersebut menjelaskan bahwa ukuran perusahaan tidak memberikan pengaruh terhadap keputusan umtuk melakukan peningkatan atau penurunan tingkat hutang. Baik perusahaan yang besar, menengah maupun yang kecil sama-sama memiliki kebutuhan hutang yang berbeda yang disesuaikan dengan kebutuhan pendanaan atau pembiayaan masingmasing perusahaan. Namun hasil penelitian ini tidak mendukung penelitian yang dilakukan oleh Öztekin (2015); Wijayanti (2018) yang memberikan hasil bahwa ukuran perusahaan memberikan pengaruh terhadap struktur modal perusahaan.

Hasil hipotesis $\mathbf{H}_{2}$ diterima, artinya $R O A$ berpengaruh negatif dan signifikan terhadap struktur modal. Hasil penelitian ini mendukung penelitian yang dilakukan oleh Astuti (2018) yang menyatakan ada pengaruh negatif dari $R O A$ terhadap struktur modal. Hal tersebut menjelaskan bahwa semakin tinggi keuntungan berdasarkan aset-aset perusahaan maka struktur modalnya semakin rendah. Karena keuntungan perusahaan digunakan untuk melunasi hutang-hutang perusahaan, sebaliknya jika keuntungan yang didapat semakin rendah, maka perusahaan akan berusaha mencari dana guna meningkatkan pendapatan perusahaan. Dana eksternal yang didapat digunakan untuk menambah aset-aset perusahaan dengan harapan dapat meningkatkan pendapatan bagi perusahaan. Hasil penelitian ini tidak sejalan dengan penelitian Firmanullah and Darsono (2017); Milansari, Masitoh, and Siddi (2020) yang menyatakan bahwa ROA tidak berpengaruh terhadap struktur modal.

Hasil hipotesis $\mathbf{H}_{\mathbf{3}}$ diterima, artinya $R O E$ berpengaruh positif dan signifikan terhadap struktur modal. Hasil penelitian ini mendukung penelitian yang dilakukan oleh oleh Herciu and Ogrean (2017); Putra and Sedana (2019); Wijayanti (2018) yang menyatakan bahwa $R O E$ berpengaruh positif terhadap keputusan struktur modal. Hubungan positif antara $R O E$ dengan struktur modal mengartikan bahwa semakin besar tingkat keuntungan yang diperoleh perusahaan maka struktur modal perusahaan yang berasal dari utang akan semakin meningkat. Hal tersebut menunjukkan besar pengembalian yang diperoleh pemilik perusahaan atas modal belum bisa membiayai kegiatan opersional dan investasi perusahaan. Akan tetapi hasil penelitian ini tidak sejalan dengan penelitian yang dilakukan oleh menurut Iqbal, Ahmad, and Ali (2019); Yulianto, Susyanti, and Salim (2018) yang menyatakan adanya pengaruh negatif $R O E$ terhadap struktur modal.

Hasil hipotesis $\mathbf{H}_{\mathbf{4}}$ ditolak, artinya inflasi tidak berpengaruh terhadap struktur modal. Hasil penelitian ini mendukung penelitian yang dilakukan oleh Mahanani and Asandimitra (2017) yang menyatakan bahwa inflasi tidak berpengaruh terhadap struktur modal. Hal tersebut menjelaskan bahwa perusahaan telah terbiasa dengan keadaan inflasi yang terjadi dan tidak lagi mempertimbangkan tingkat inflasi. Karena sudah tidak lagi memperhatikan faktor 
inflasi selama masih dalam keadaan stabil, perusahaan akan menyesuaikan rasio hutangnya sesuai dengan kebutuhan operasional dan investasi perusahaan. Namun hasil penelitian tidak sejalan dengan penelitian yang dilakukan oleh Budiono and Septiani (2017) yang menyatakan bahwa inflasi memberikan pengaruh terhadap keputusan struktur modal.

Hasil hipotesis $\mathbf{H}_{5}$ ditolak, artinya PDB tidak berpengaruh terhadap struktur modal. Hasil penelitian ini mendukung hasil penelitian yang dilakukan oleh Mahanani and Asandimitra (2017) yang menyatakan Herciu and Ogrean (2017) yang menyatakan bahwa tidak ada pengaruh PDB terhadap struktur modal. Hal tersebut menjelaskan bahwa perusahaan telah terbiasa dengan keadaan ekonomi di Indonesia. Laba bukan lagi menjadi sinyal bagi para investor yang menunjukkan bahwa perusahaan memiliki prospek yang baik, namun investor memilih perusahaan tersebut dengan alasan mampu bertahan dalam berbagai kondisi dan telah lama berdiri. Umur perusahaan memberikan petunjuk bahwa perusahaan tetap eksis, mampu bersaing dan dapat memanfaatkan peluang bisnis dalam suatu perekonomian. Oleh karena itu, bagaimanapun kondisi PDB suatu perekonomian, perusahaan tersebut dapat bertahan dan memiliki prospek yang baik serta tidak mempengaruhi proporsi hutang perusahaan. Namun hasil penelitian ini tidak mendukung penelitian yang dilakukan oleh Yildirim, Masih, and Bacha (2018); Aktas, Bilge, and Celik (2015) yang menyatakan adanya pengaruh pertumbuhan PDB terhadap struktur modal.

\section{KESIMPULAN}

Ternyata ukuran perusahaan, inflasi dan pertumbuhan PDB tidak berpengaruh terhadap struktur modal. Sedangkan $R O A$ berpengaruh negatif dan signifikan terhadap struktur modal. Sementara itu $R O E$ berpengaruh positif dan signifikan terhadap struktur modal. Hal ini menunjukkan bahwa perusahaan tidak melihat kondisi makro ekonomi sebagai landasan untuk membuat kebijakan struktur modal, khususnya di Indonesia. Ditambah lagi dengan kondisi inflasi yang stabil dan dapat dikendalikan dan pertumbuhan PDB yang masih bisa diprediksi, sehingga perusahaan akan fokus dengan keadaan mikro ekonomi sebagai landasan dalam membuat keputusan struktur modal.

Penelitian ini menunjukkan bahwa perusahaan lebih mengutamakan pengembalian ekuitas kepada para pemegang saham. Sehingga dapat memberi sinyal kepada para calon investor bahwa perusahaan tersebut memiliki tingkat pengembalian yang tinggi kepada para pemegang saham. Disisi lain, aset-aset perusahaan cenderung dilupakan karena keuntungan yang lebih difokuskan kepada pada pemegang ekuitas. Adapun keterbatasan pada penelitian ini adalah sampel yang digunakan terbatas pada perusahaan yang terdaftar di $J I I$, tahun uji yang digunakan terbatas dari tahun 2015 hingga 2019, dan variabel bebas terbatas pada lima variabel.

Masih banyak faktor-faktor yang mungkin dapat mempengaruhi keputusan perusahaan untuk membentuk struktur modal. Oleh karena itu, penelitian lanjutan diperlukan. Masih banyak hal yang perlu ditambahkan dalam penelitian ini, seperti jumlah sampel yang lebih banyak lagi agar dapat mewakili keadaan struktur modal perusahaan yang sebenarnya, tahun uji yang lebih lama serta variabel-variabel lainnya yang tidak digunakan dalam penelitian ini. Kemudian 
diharapkan juga kepada manajemen perusahaan juga bisa memanfaatkan hasil penelitian ini agar dapat membentuk struktur modal yang ideal dan sesuai dengan tujuan masing-masing perusahaan.

\section{DAFTAR PUSTAKA}

Akgul, Ersin Firat, and Secil Sigali. 2018. "Determinants of Capital Structure: An Application on BIST Transportation Index." The Journal of Accounting and Finance, 193-215. http://journal.mufad.org.tr/attachments/article/924/12.pdf.

Aktas, Rafet, Bakin Bilge, and Gokhan Celik. 2015. "The Determinants of Banks Capital Adequacy Ratio: Some Evidence from South Eastern European Countries." Journal of Economics and Behavioral Studies 7 (1(J)): 79-88. https://doi.org/10.22610/jebs.v7i1(j).565.

Albart, Nicko, Bonar Marulitua Sinaga, Perdana Wahyu Santosa, and Trias Andati. 2020. "The Effect of Corporate Characteristics on Capital Structure in Indonesia." Journal of Economics, Business, \& Accountancy Ventura 23 (1): 46-56. https://doi.org/10.14414/jebav.v23i1.2153.

Arifin, Syamsul, and Yoyok Soesatyo. 2020. Pertumbuhan Ekonomi, Tingkat Pengangguran Dan Konsumsi, Dalam Bingkai Kesejahteraan Masyarakat. Banyumas: CV. Pena Persada.

Astuti, Elly. 2018. "Determinant Capital Structure of Banking Company in Indonesia." Kinerja Journal of Business and Economics 22 (1): 69-78. https://ojs.uajy.ac.id/index.php/kinerja/article/view/1236.

Berkman, Ayberk Nuri, Omer Iskenderoglu, Erdinc Karadeniz, and Nazif Ayyildiz. 2016. "Determinants of Capital Structure: The Evidence from European Energy Companies." International Journal of Business Administration 7 (6): 96-106. https://doi.org/10.5430/ijba.v7n6p96.

Brian, Kinyua John, and Peter W. Muriu. 2017. "Determinants of Capital Structure of Agricultural Firms in Kenya." European Scientific Journal (ESJ) 13 (7): 1-41. https://doi.org/10.19044/esj.2017.v13n7p277.

Budiono, Budiono, and Nur Septiani. 2017. "Pengaruh Inflasi, Suku Bunga SBI, Kurs US Dollar Terhadap Rupiah, Pajak, Solvabilitas Dan Profitabilitas Terhadap Struktur Modal Pada Perusahaan LQ-45 Yang Terdaftar Di Bursa Efek Indonesia Periode 2010-2015." BISMA - Bisnis Dan Manajemen 9 (2): 119-34. https://doi.org/10.26740/bisma.v9n2.p119-134.

Duli, Nikolaus. 2019. Metodologi Penelitian Kuantitatif: Beberapa Konsep Dasar Untuk Penulisan Skripsi \& Analisis Data Dengan SPSS. Sleman: Deepublish.

El-Ansary, Osama, and Hassan Hafez. 2015. "Determinants of Capital Adequacy Ratio: An Empirical Study On Egyptian Banks." Corporate Ownership \& Control 13 (1): 806-16. https://ssrn.com/abstract=2708603.

Fauziah, Fenty, and Rusdiah Iskandar. 2015. "Determinants of Capital Structure in Indonesian Banking Sector." International Journal of Business and Management Invention 4 (12): 36-44. https://www.ijbmi.org/papers/Vol(4)12/E04012036044.pdf.

Firmanullah, Nurul, and Darsono Darsono. 2017. "Faktor-Faktor Yang 
Mempengaruhi Struktur Modal Di Perusahaan Indonesia (Pada Perusahaan Manufaktur Yang Terdaftar Di BEI Tahun 2011-2014)." Diponegoro Journal of Accounting 6 (3): 1-9. https://ejournal3.undip.ac.id/index.php/accounting/article/view/18234.

Gharaibeh, Ahmad Mohammad Obeid. 2015. "The Determinants of Capital Structure: Empirical Evidence from Kuwait." European Journal of Business, Economics and Accountancy 3 (6): 1-25. http://www.idpublications.org/wp-content/uploads/2015/09/THEDETERMINANTS-OF-CAPITAL-STRUCTURE-EMPIRICALEVIDENCE-FROM-KUWAIT.pdf.

Herciu, Mihaela, and Claudia Ogrean. 2017. "Does Capital Structure Influence Company Profitability?" Studies in Business and Economics 12 (3): 50-62. https://doi.org/10.1515/sbe-2017-0036.

Iqbal, Fatima, Muhammad Bilal Ahmad, and Hafiz Fawad Ali. 2019. "Determinants of Capital Structure: An Empirical Study of KSE Listed MNCs in Pakistan." Journal of Accounting, Finance and Auditing Studies (JAFAS) 5 (1): 173-95. https://doi.org/10.32602/jafas.2019.8.

Istiqamah, Mila, and Supriyanto Supriyanto. 2017. "Analisis Struktur Modal Perbankan Syariah Di Indonesia." Jurnal Penelitian 14 (2): 201-14. https://doi.org/10.28918/jupe.v14i2.1216.

Kontesa, Maria. 2015. "Capital Structure, Profitability, And Firm Value . Whats New?" Research Journal of Finance and Accounting 6 (20): 185-92. https://core.ac.uk/download/pdf/234631139.pdf.

Mahanani, Rahayu Mukti, and Nadia Asandimitra. 2017. "Pengaruh Nilai Tukar, Suku Bunga, Inflasi, Gdp Dan Corporate Tax Rate Terhadap Struktur Modal Perusahaan Sektor Infrastruktur, Utilitas Dan Transportasi Yang Terdaftar Di Bursa Efek Indonesia Tahun 2011-2015." Jurnal Ilmu $\begin{array}{lllll}\text { Manajemen } & \text { (JIM) } & 5 & (3): & 1-11 .\end{array}$ https://ejournal.unesa.ac.id/index.php/jim/article/view/21114.

Milansari, Rani, Endang Masitoh, and Purnama Siddi. 2020. "Analysis on the Factors Affecting Capital Structure on Food and Beverage Companies in IDX.” BAKI (Berkala Akuntansi Dan Keuangan Indonesia) 5 (1): 31-46. https://doi.org/10.20473/baki.v5i1.17179.

Naser, Kamal, Abdullah Al-Mutairi, Ahmad Al Kandari, and Rana Nuseibeh. 2015. "International Journal of Economics and Financial Issues Cogency of Capital Structure Theories to an Islamic Country: Empirical Evidence from the Kuwaiti Banks." International Journal of Economics and $\begin{array}{lllll}\text { Financial } & \text { Issues } & 5 & \text { (4): }\end{array}$ https://dergipark.org.tr/en/pub/ijefi/issue/31971/352229.

Öztekin, Özde. 2015. "Capital Structure Decisions around the World: Which Factors Are Reliably Important?" Journal of Financial and Quantitative Analysis 50 (3): 301-23. https://doi.org/10.1017/S0022109014000660.

Putra, I Gede Wibawa Reska, and Ida Bagus Panji Sedana. 2019. "Capital Structure as a Mediation Variable: Profitability and Liquidity on Company Value in Real Estate Companies in Indonesia Stock Exchange." International Research Journal of Management, IT and Social Sciences 6 (4): 62-72. https://doi.org/10.21744/irjmis.v6n4.640.

Putri, Julia, and Ruzikna Ruzikna. 2016. "Pengaruh Struktur Modal Terhadap 
Nilai Perusahaan Pada Perusahaan Manufaktur Go Publik (Studi Kasus Sektor Makanan Dan Minuman)." Jurnal Online Mahasiswa Fakultas Ilmu Sosial Dan Ilmu Politik Universitas Riau 3 (2): 1-12. https://jom.unri.ac.id/index.php/JOMFSIP/article/view/11442.

Ramadhini, Gita, and M. Fuad Hadziq. 2017. "Analisis Determinan Yang Mempengaruhi Struktur Modal Pada Perbankan Syariah Di Indonesia (Periode 2011-2016)." Universitas Islam Negeri Syarif Hidayatullah Jakarta. https://repository.uinjkt.ac.id/dspace/handle/123456789/36292.

Rapanna, Patta, and Zulfikry Sukarno. 2017. Ekonomi Pembangunan. Makassar: CV. Sah Media.

Rehan, R., and A. R. Abdul Hadi. 2019. "Capital Structure Determinants of Shariah and Non-Shariah Companies at Bursa Malaysia - Dynamic Approach." International Journal of Innovation, Creativity and Change 6 (8):

334-45.

https://www.ijicc.net/images/Vol6Iss8/6823_Rehan_2019_E_R.pdf.

Setyanti, Sri Wiranti. 2009. "Analisis Faktor-Faktor Yang Mempengaruhi Struktur Modal Sebelum Dan Selama Krisis Ekonomi Pada Perusahaan Non Finansial Yang Go Publik Di Indonesia.” Jurnal STIE Semarang 1 (1): $58-69$. http://jurnal3.stiesemarang.ac.id/index.php/jurnal/article/view/242.

Shah, Syed Muhammad Abdul Rehman, Abdul Rashid, and Muhammad Khaleequzzaman. 2017. "Capital Structure Decisions in Islamic Banking: Empirical Evidence from Pakistan." Journal of Islamic Banking and Finance 34 (June): 88-103. https://ssrn.com/abstract=3469031.

Sugeng, Bambang. 2017. Manajemen Keuangan Fundamental. Sleman: Deepublish.

Sumedrea, Silvia. 2015. "How the Companies Did Structure Their Capital to Surpass Crises?" Procedia Economics and Finance 27 (15): 22-28. https://doi.org/10.1016/s2212-5671(15)00967-3.

Wijayanti, Marsa Nurlita. 2018. "Pengaruh Variabel Makroekonomi Dan Mikroekonomi Terhadap Struktur Modal Perusahaan.” Universitas Islam Indonesia. https://dspace.uii.ac.id/handle/123456789/12734.

Yildirim, Ramazan, Mansur Masih, and Obiyathulla Ismath Bacha. 2018. "Determinants of Capital Structure: Evidence from Shari'ah Compliant and Non-Compliant Firms." Pacific-Basin Finance Journal 51 (October): 198-219. https://doi.org/10.1016/j.pacfin.2018.06.008.

Yulianto, Alfiananda Dwi, Jeni Susyanti, and M. Agus Salim. 2018. "Pengaruh Inflasi, Suku Bunga SBI, Tarif Pajak Dan Profitabilitas Terhadap Struktur Modal (Studi Kasus Pada Perusahaan Manufaktur Subsektor Logam Dan Sejenisnya Yang Terdaftar Di Bursa Efek Indonesia Selama Periode 20142017)." Jurnal Ilmiah Riset Manajemen, 1-13. http://riset.unisma.ac.id/index.php/jrm/article/view/2317. 